\title{
Extra- and Intra-cellular $\alpha$-L-Arabinofuranosidase of Sclerotinia fructigena
}

\author{
By F. LABORDA, A. H. FIELDING AND R. J. W. BYRDE \\ Long Ashton Research Station, University of Bristol, Bristol
}

(Received 29 May 1973)

\begin{abstract}
SUMMARY
The production of both intracellular and extracellular $\alpha$-L-arabinofuranosidase (AF) by Sclerotinia fructigena was demonstrated. They had different kinetic parameters, $\mathrm{pH}$ stability and optimal $\mathrm{pH}$ values. Two peaks of activity were found on gel filtration: maximum activity was associated with the peak of lower molecular weight in the culture filtrate, but with the higher molecular weight peak in the mycelial homogenate.

Isoelectric-focusing studies on culture filtrates revealed two peaks of AF activity with pI 3.0 and 6.5 respectively, maximum activity being associated with the latter. In the mycelial homogenate, most of the activity was associated with a third peak of activity with pI $4 \cdot 5$.

Physical and kinetic data suggest that the two AF activities present externally in the culture filtrates are identical with the two internal ones, with corresponding pI.
\end{abstract}

\section{INTRODUCTION}

The important role that host-cell-wall degrading enzymes produced by plant pathogenic fungi play in pathogenicity has been widely described (see reviews by Bateman \& Millar, 1966; Albersheim, Jones \& English, 1969). Among these lytic enzymes, production of $\alpha$-L-arabinofuranosidase (AF) by several plant-pathogenic fungi has been reported (Fuchs, Jobson \& Wonts, 1965; Akinrefon, 1968; Kaji \& Yoshihara, 1969; Keegstra, English \& Albersheim, 1972). Production of AF by Sclerotinia fructigena was also demonstrated by Byrde \& Fielding (1965). Studies with isolates of this fungus obtained after mutagen treatment indicated an important role for AF during mycelial advance in apple tissue (Howell, 1972).

Although production of host-cell-wall degrading enzymes by plant-pathogenic fungi often seems to be dependent upon environmental conditions (Albersheim et al. 1969), in general biosynthesis and secretion of enzymes by fungi are not fully understood. There are indications that both in yeast and moulds secretion of enzymes may be associated with molecular changes in the active protein before they are secreted (Liras \& Gascon, I97I; Trevithick \& Metzenberg, 1964).

All studies to date on fungal AF enzymes have been concerned with extracellular activity. Because Calonge, Fielding \& Byrde (I969) suggested the possibility that AF activity may be associated with multivesicular bodies within the cytoplasm of Sclerotinia fructigena, the relationship of intracellular and extracellular AF activity was studied.

A brief account of some of the present work has previously been published (Laborda, Hislop, Fielding \& Byrde, 1972).

* Present address: Department of Plant Pathology, University of Wisconsin, Madison, Wisconsin 53706, U.S.A. 


\section{METHODS}

Fungal culture. The culture of Sclerotinia fructigena Aderh. \& Ruhl. was grown either on V-8 agar or in ammonium tartrate-sodium polypectate liquid medium as previously described (Byrde \& Fielding, 1968).

Production of enzyme. Five-hundred-ml conical flasks containing $150 \mathrm{ml}$ ammonium tartrate-sodium polypectate liquid medium were inoculated with a suspension of spores, from two 8-10 days old cultures on V-8 agar slopes, and incubated at $25^{\circ} \mathrm{C}$ in a reciprocal shaker. After 4 days, cultures were harvested by filtration. Culture filtrates were dialysed against distilled water for 24 to $48 \mathrm{~h}$ at $4{ }^{\circ} \mathrm{C}$. After washing several times with distilled water, mycelium was broken in a mortar at $0^{\circ} \mathrm{C}$ by using washed sand as an abrasive. Breakage sequence was followed by phase-contrast microscopy. Unbroken mycelium, cell walls and sand were separated by centrifugation at $2000 \mathrm{~g}$ for $20 \mathrm{~min}$. Supernatants were centrifuged for $30 \mathrm{~min}$ at $30000 \mathrm{~g}$ in a refrigerated MSE High-speed 18 . When needed, both culture filtrate and mycelial homogenate were concentrated in a Leybold-Heraeus freeze drier, Model SB4.

Estimation of $\alpha$-L-arabinofuranosidase ( $\alpha$-L-arabinofuranoside arabinohydrolase) activity. For routine assay, $25 \mathrm{mg}$ of substrate ( $p$-nitrophenyl- $\alpha$-L-arabinofuranoside; Fielding \& Hough, 1965) were dissolved in $100 \mathrm{ml}$ of $0 . \mathrm{I}$ M-sodium acetate buffer, $\mathrm{pH} 4.7 ; 2.5 \mathrm{ml}$ of this solution were incubated with $\mathrm{I} \mathrm{ml}$ of enzyme preparation at $30{ }^{\circ} \mathrm{C}$. The reaction was stopped by addition of $\mathrm{I} \mathrm{ml}$ of saturated solution of sodium carbonate; $p$-nitrophenol liberated was measured at $403 \mathrm{~nm}$ in a CE 272 Linear Readout Ultraviolet Spectrophotometer.

To study the $\mathrm{pH}$ activity and $\mathrm{pH}$ stability of the different enzymes, the borate-citratephosphate buffer system of Teorell \& Stenhagen (1938) was used.

Gel filtration. The different AF activities were separated by using either Sephadex G-I00 bead form or Biogel P-300 (50 to I50 mesh) columns $(4 \times 80 \mathrm{~cm}$ ) equilibrated with $0.05 \mathrm{M}$ tris-hydrochloric acid buffer, $\mathrm{pH} 7.5$, containing $0.1 \mathrm{M}$-potassium chloride and $0.02 \%$ sodium azide. One $\mathrm{ml}$ of enzyme preparation containing sucrose was layered on the top of the column, and $3 \mathrm{ml}$ fractions were collected. The Sephadex G-Ioo column was eluted by gravity, whereas the Biogel P-300 one was eluted with an LKB peristaltic pump. Flow rate through both columns was $12 \mathrm{ml} / \mathrm{h}$. The same columns were used for molecular weight estimations of the different AF molecular forms by the method of Andrews (1964).

Isoelectric focusing. The method of Vesterberg \& Svensson (1966) was followed using an LKB I I0 ml column and carrier ampholytes at a final concentration of I \% (w/v) to establish the $\mathrm{pH}$ gradient. The enzyme preparation was applied in the light solution of the sucrose gradient. A dense lower-anode solution was prepared using $0.6 \%$ phosphoric acid and an upper-cathode solution of $2 \%$ ethylene diamine. The voltage applied was usually $200 \mathrm{~V}$ giving a current of $10 \mathrm{~mA}$, increasing to about $600 \mathrm{~V}$ with a current $<2.0 \mathrm{~mA}$. Each run was for $64 \mathrm{~h}$ at $10{ }^{\circ} \mathrm{C}$. The column was drained off by gravity flow through capillary tubing and collected in $4.5 \mathrm{ml}$ fractions.

Protein was measured by the method of Lowry, Rosebrough, Farr \& Randall (195I), with bovine-serum albumin as standard. 
Table r. AF distribution in a 4-day-old culture of Sclerotinia fructigena

$\begin{array}{lccc} & \begin{array}{c}\text { Total activity } \\ (\mu \mathrm{mol} / \mathrm{min})\end{array} & \begin{array}{c}\text { Protein } \\ (\mathrm{mg})\end{array} & \begin{array}{c}\text { Specific } \\ \text { activity }\end{array} \\ \text { Culture filtrate } & 140 & 216 & 0.64 \\ \text { Mycelial homogenate } & 19 & 170 & 0.13\end{array}$

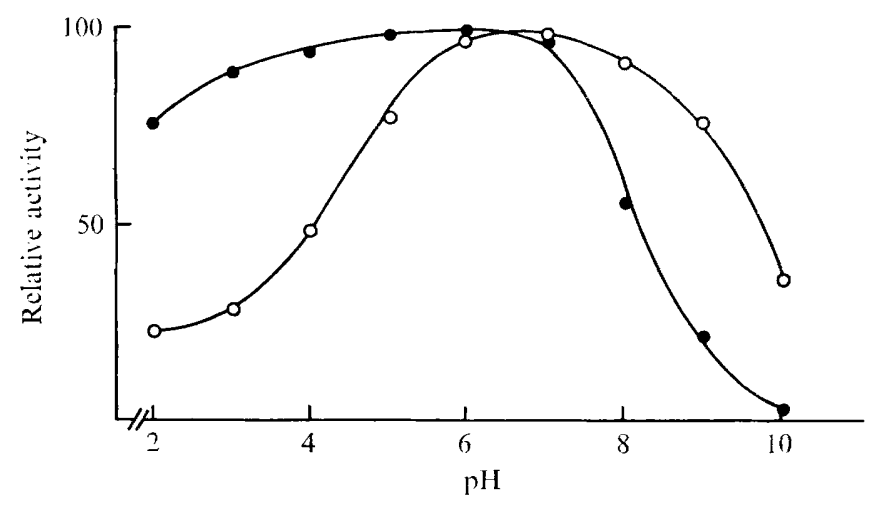

Fig. I. pH/stability relationships for intracellular $(0)$ and extracellular $(\bullet)$ $\alpha$-L-arabinofuranosidase of Sclerotinia fructigena.

\section{RESULTS}

\section{Localization of AF activity}

In a 4-day-old culture filtrate, $\mathrm{AF}$ activity was detected both in the culture filtrate (' $E$ ') and in the mycelial homogenate (' $I$ '), the total activity detected in the culture filtrate being 7 to 8 times higher than in the mycelial homogenate (Table I). During the incubation period the $\mathrm{pH}$ of the culture medium rose from $5 \cdot 2$ to $6 \cdot 8$.

\section{Properties of intracellular and extracellular $A F$}

The $p H$ stability of both ' $\mathrm{E}$ ' and ' $\mathrm{I}$ ' preparations was measured by incubating I vol. of buffer +9 vol. of enzyme over the $\mathrm{pH}$ range 2 to 10 at $30^{\circ} \mathrm{C}$. After $30 \mathrm{~min}$ incubation, residual activity was measured at $\mathrm{pH} 4.7$ under the standard conditions. ' $E$ ' was stable over the $\mathrm{pH}$ range 4 to 7 , but ' $\mathrm{I}$ ' was stable only at $\mathrm{pH} 6$ to 7 . Generally, ' $E$ ' was more stable under acid conditions, while 'I' was more stable at higher $\mathrm{pH}$ values (Fig. I).

pH activity. One vol. of enzyme +2 vol. of buffer +0.5 vol. of substrate ( $\mathrm{mg} / \mathrm{ml}$ water) were incubated at $30^{\circ} \mathrm{C}$ for $15 \mathrm{~min}$. Activity was expressed as per cent of the maximum value. Results are plotted in Fig. 2. Maximum activity for ' $E$ ' was at $\mathrm{pH} 4.5$, and that for ' $\mathrm{I}$ ' was at $\mathrm{pH} 5.5$ to 6.0 (Fig. 2). The Figure shows a similar pattern to that for $\mathrm{pH}$ stability, viz. ' $\mathrm{E}$ ' was more active at acid $\mathrm{pH}$, and ' $\mathrm{I}$ ' was more active at high $\mathrm{pH}$ values.

The effect of substrate concentration was studied over a range from 0.25 to $2.0 \mathrm{~mm}$ at both $\mathrm{pH} 4.5$ and 5.5 in $0 . \mathrm{I} \mathrm{M}$-acetate buffer. The Lineweaver-Burk plots obtained gave $K_{m}$ values for ' $\mathrm{I}$ ' of $0.28 \mathrm{mM}$ at $\mathrm{pH} 4.5$ and $0.23 \mathrm{~mm}$ at $\mathrm{pH} 5.5$, and for ' $\mathrm{E}$ ' of $0.66 \mathrm{~mm}$ at $\mathrm{pH} 4.5$ and $\mathrm{I} \cdot \mathrm{x} \mathrm{mM}$ at $\mathrm{pH} 5 \cdot 5$.

Gel filtration. Either a culture filtrate or a mycelial homogenate was applied to a column of Sephadex G-I00 and eluted as described under Methods. The patterns obtained for both elutions are shown in Fig. 3; the results are expressed as per cent of maximum activity 


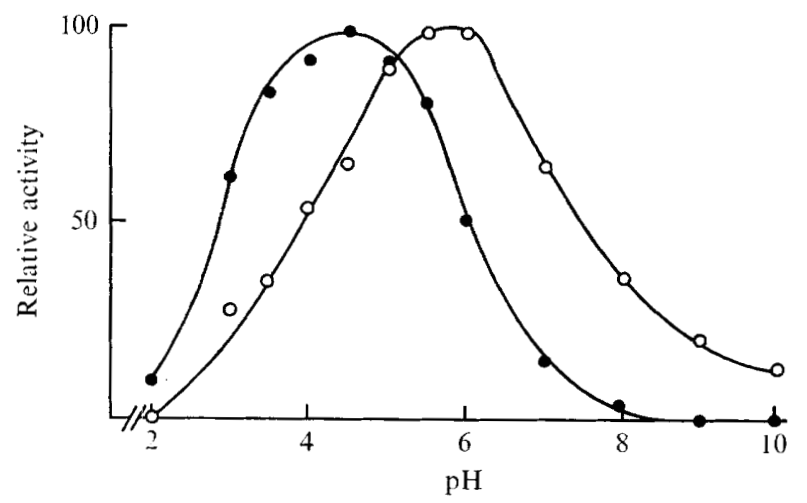

Fig. 2. pH/activity relationships for intracellular $(O)$ and extracellular $(0$ $\alpha$-L-arabinofuranosidase of Sclerotinia fructigena.

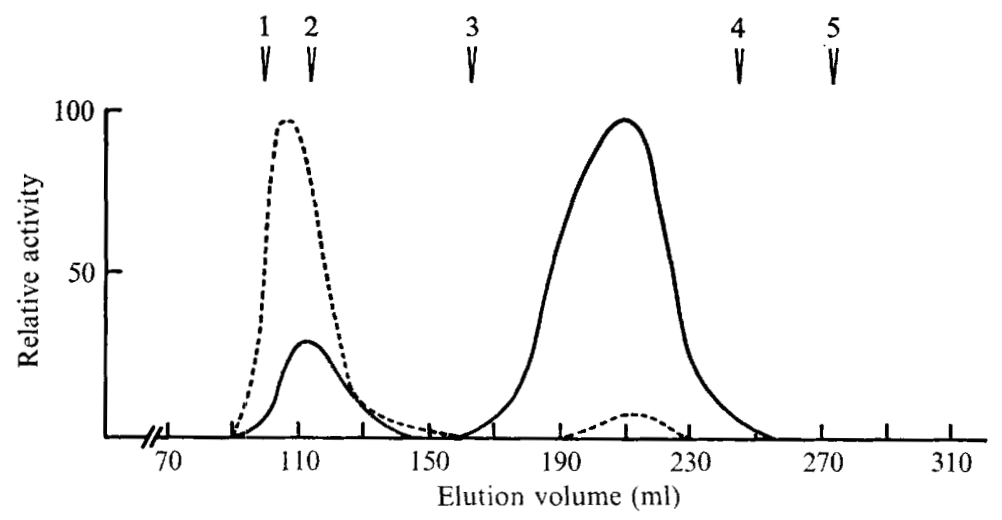

Fig. 3. Elution pattern of intracellular (---) and extracellular (-) $\alpha$-L-arabinofuranosidase of Sclerotinia fructigena on Sephadex G-I00. (Elution volumes are indicated for: I, dextran blue; 2, $\gamma$-globulin; 3 , serum-albumin fraction V; 4 , trypsin inhibitor; 5 , cytochrome $c$.)

obtained. Two peaks of AF activity were found in both preparations, but while in the culture filtrate maximum activity was associated with the peak which had a $V_{e} / V_{o}$ value of $2 \cdot \mathrm{I}$, in the mycelial homogenate maximum activity was associated with the peak which was excluded with the $V_{o}$. The elution pattern of several proteins with known molecular weight is also shown.

Isoelectric-focusing studies. Isoelectric focusing over a wide $\mathrm{pH}$ range ( $\mathrm{pH} 3$ to 10 ) was used to separate the different AF activities from both culture filtrate and mycelial homogenate. The culture filtrate showed two peaks of AF activity with isoelectric points 3.0 and 6.5 , maximum activity being associated with the peak with $\mathrm{pI} 6 \cdot 5$. The mycelial homogenate also showed peaks of activity with $\mathrm{pI} 3.0$ and 6.5 , but maximum activity was associated with a third peak which had pI 4.5 (Fig. 4).

\section{Properties of the different AF enzymatic activities}

Corresponding peak-activity fractions from several isoelectric-focusing experiments, either from mycelial homogenate or from culture filtrate, were pooled and dialysed against $\mathrm{O} \cdot \mathrm{I} \mathbf{M}$ phosphate buffer, pH $7 \cdot 0$, at $4{ }^{\circ} \mathrm{C}$ for 18 to $24 \mathrm{~h}$. The different samples were studied on the basis of their $\mathrm{pH}$ activity, $\mathrm{pH}$ stability, thermal inactivation, $K_{m}$ and apparent molecular weight. 


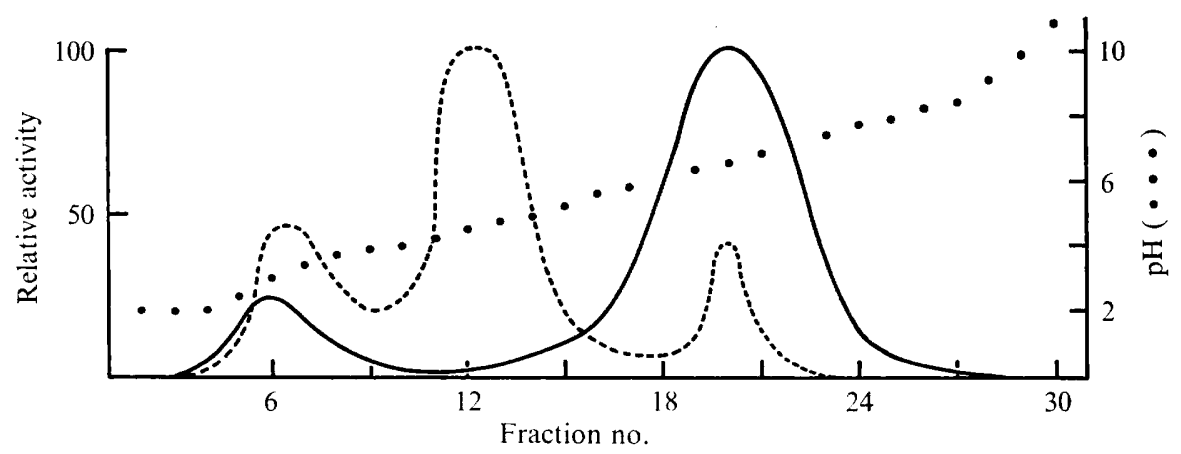

Fig. 4. Isoelectric focusing of intracellular (---) and extracellular (-) $\alpha$-L-arabinofuranosidase of Sclerotinia fructigena. (....), $\mathrm{pH}$ gradient.
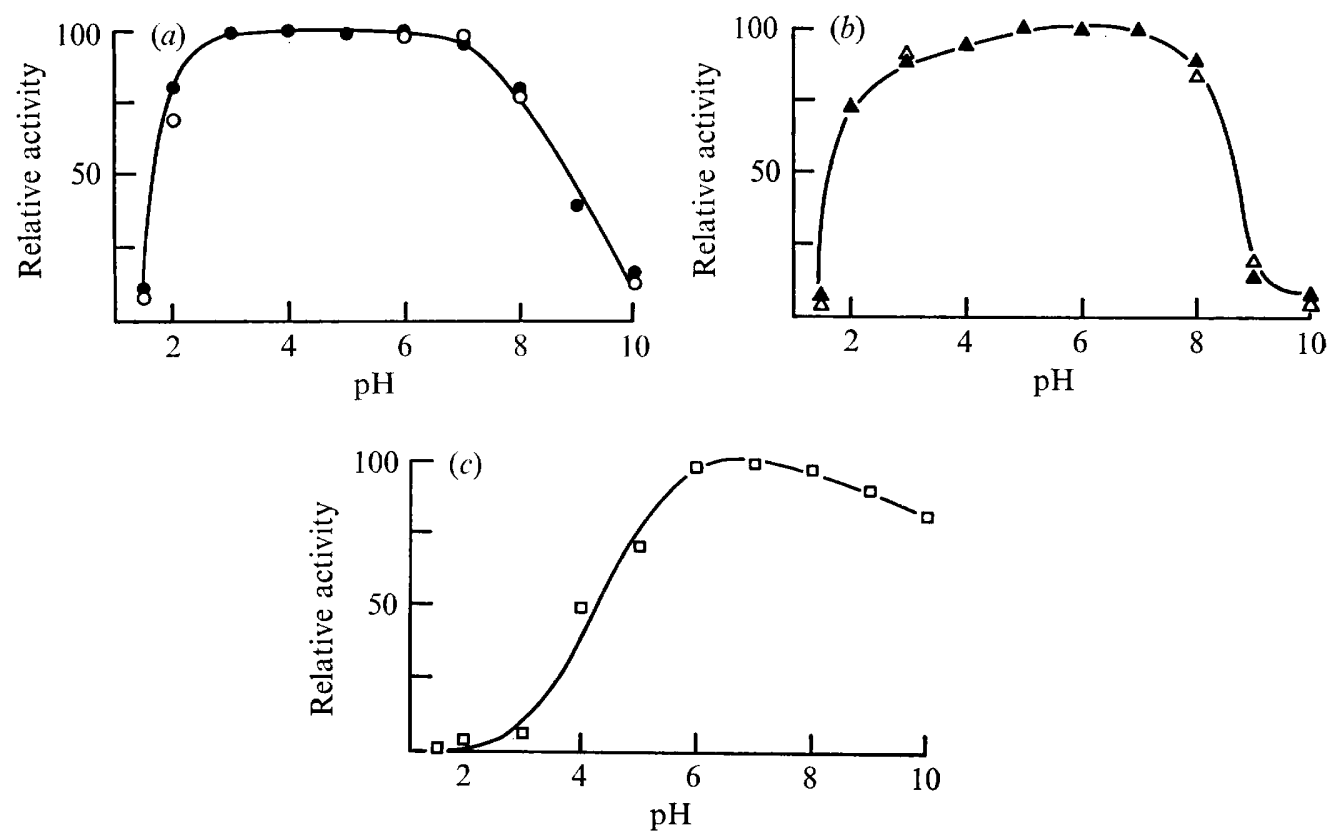

Fig. 5. $\mathrm{pH} / \mathrm{stability}$ relationships for $\alpha$-L-arabinofuranosidase isoenzymes of Sclerotinia fructigena. (a) Isoenzymes with pI $3 \cdot 0$. (b) Isoenzymes with pI 6.5. (c) Isoenzyme with pI 4.5. (Open symbols, internal isoenzymes. Closed symbols, external; internal also where coincident.)

$p H$ stability was studied as described previously. The two isoenzymes (using the term in a functional sense) with pI 3.0 and those with pI 6.5 were shown to be stable at $\mathrm{pH} 3$ to 8 but not at alkaline $\mathrm{pH}$ values, while the internal isoenzyme with $\mathrm{pI} 4.5$ was stable at $\mathrm{pH}$ values near neutrality but not at acid ones (Fig. 5).

pH activity was studied as previously described. Results plotted in Fig. 6 show a similar behaviour for those internal and external isoenzymes with the same isoelectric point, but while those with $\mathrm{pI} 3.0$ showed maximum activity at $\mathrm{pH} 3$ to 4 , and those with $\mathrm{pI} 6.5$ at $\mathrm{pH} 5 \cdot 0$, the isoenzyme with $\mathrm{pI} 4.5$ had maximum activity at $\mathrm{pH} 5 \cdot 7$ to $6 \cdot 0$, being almost completely inactive at $\mathrm{pH}$ values below 4 (Fig. 6).

Thermal inactivation was studied by incubating I $\mathrm{ml}$ of enzyme at different temperatures 

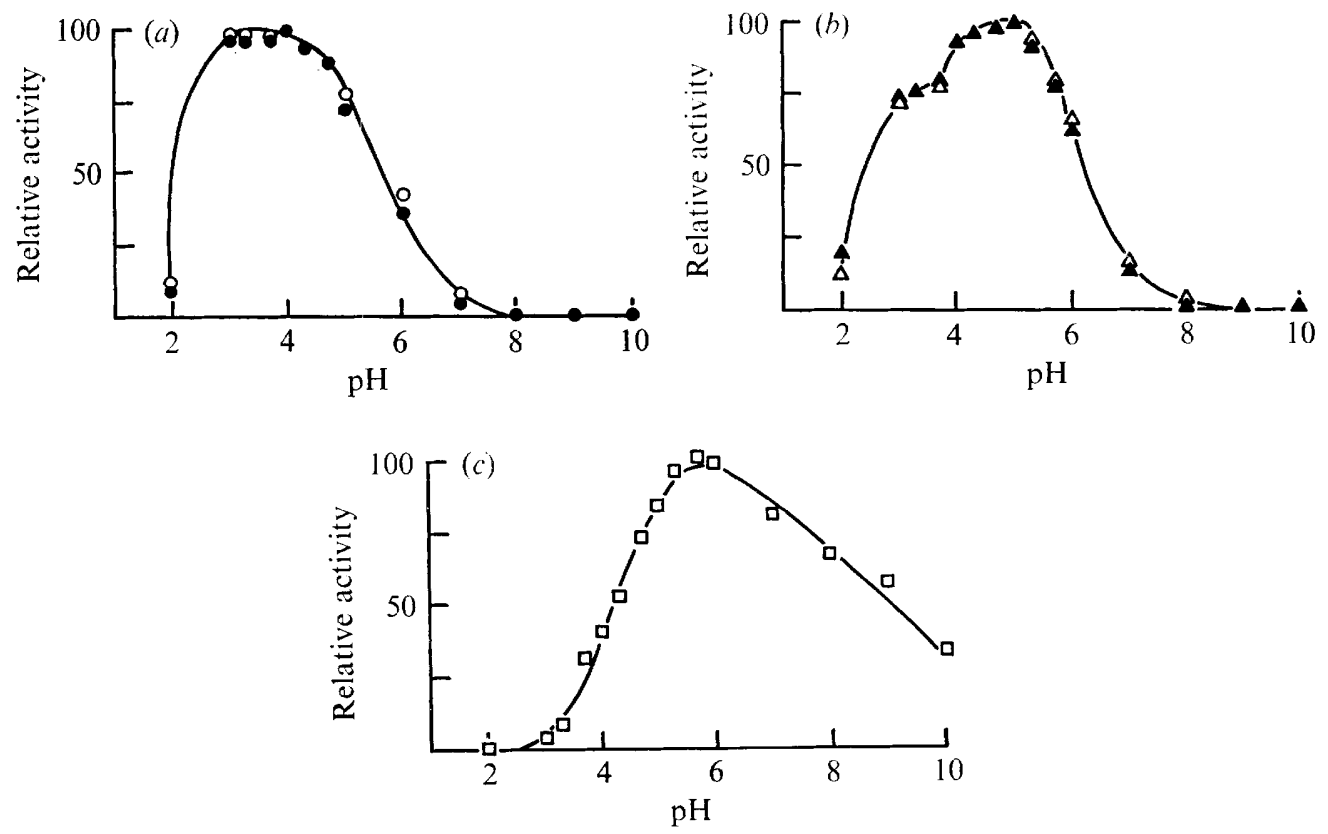

Fig. 6. $\mathrm{pH} /$ activity relationships for $\alpha$-L-arabinofuranosidase isoenzymes of Sclerotinia fructigena. For details, see Fig. 5.
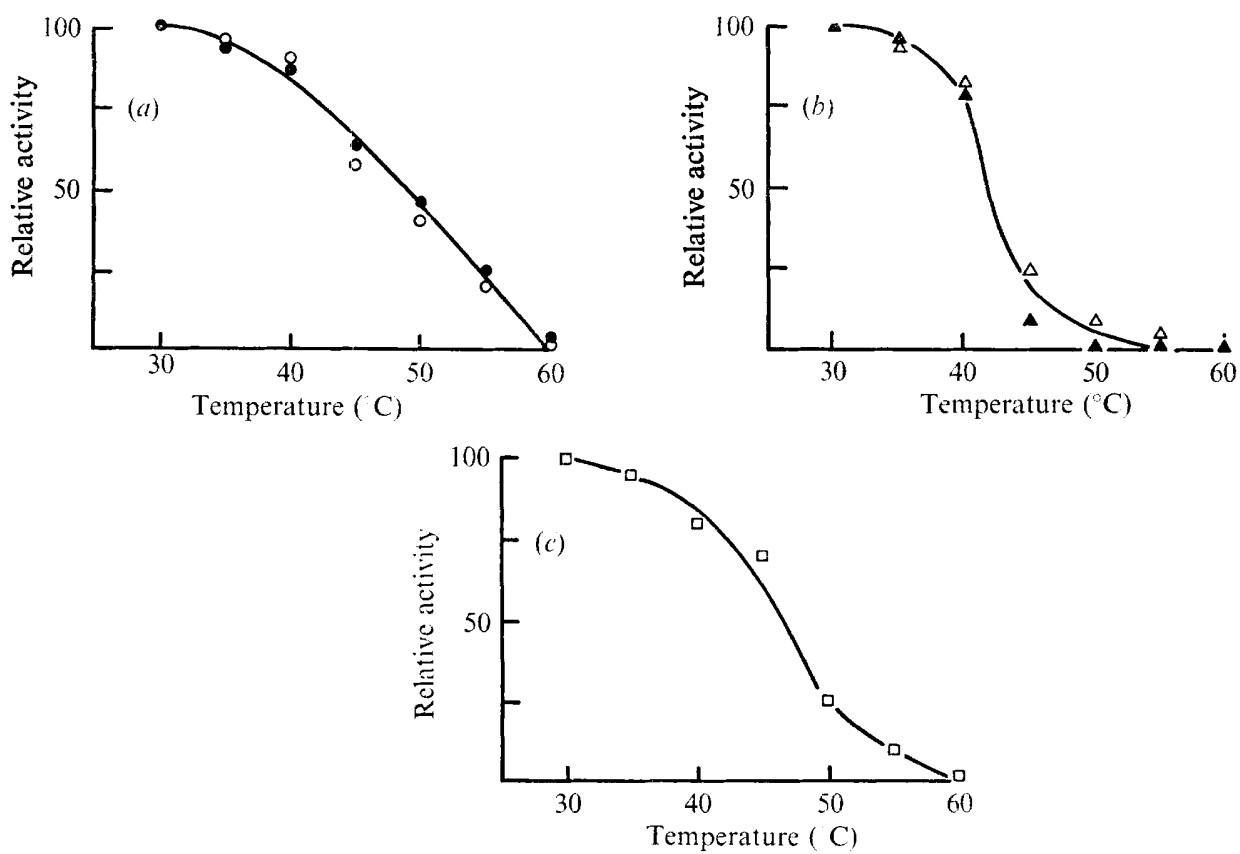

Fig. 7. Thermal inactivation (10 min exposure) of $\alpha$-L-arabinofuranosidase isoenzymes of Sclerotinia fructigena. For details, see Fig. 5. 


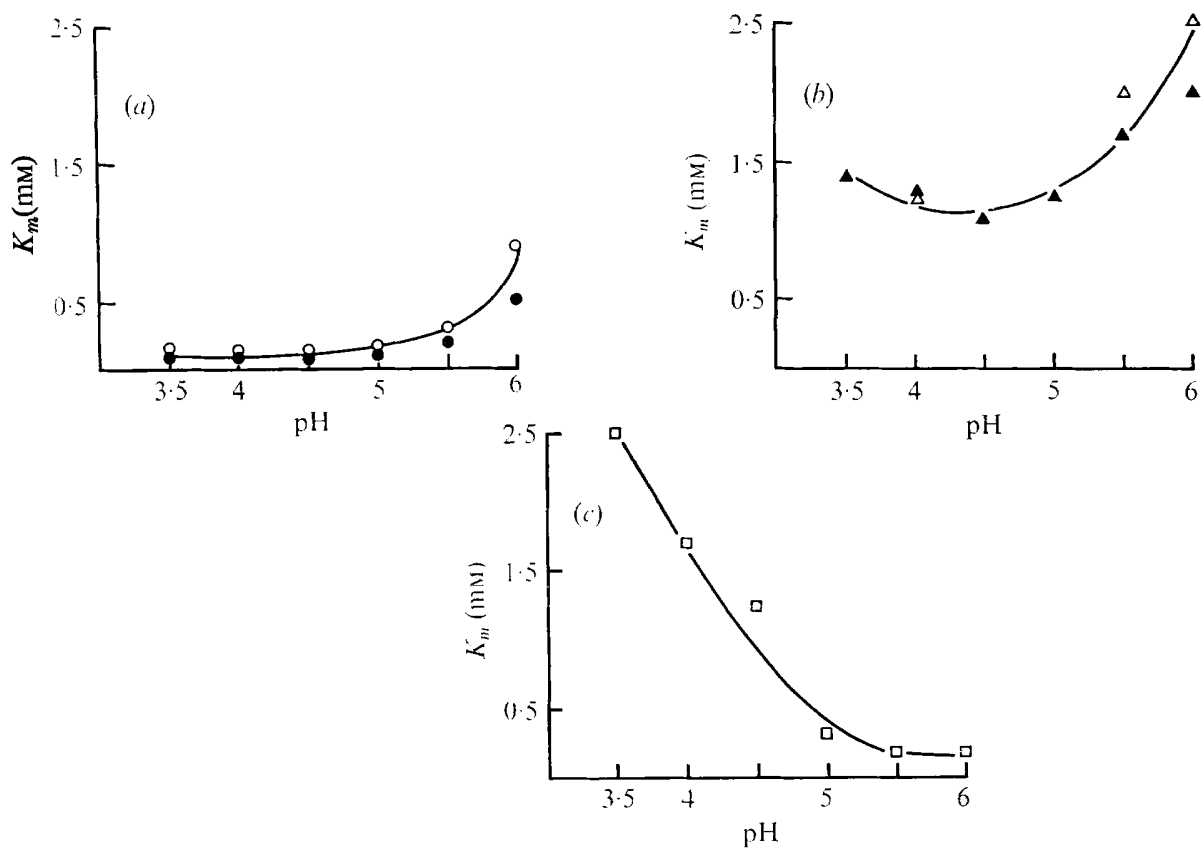

Fig. 8. Effect of $\mathrm{pH}$ on the $K_{m}$ of $\alpha$-L-arabinofuranosidase isoenzymes of Sclerotinia fructigena. For details, see Fig. 5.

for $10 \mathrm{~min}$, then cooling rapidly to about $0{ }^{\circ} \mathrm{C}$ by immersion of the tube in acetone at $-20{ }^{\circ} \mathrm{C}$. Residual activity was measured at $\mathrm{pH} 4.7$ under the standard conditions. The results show a similar behaviour for isoenzymes with the same pI (Fig. 7). Isoenzymes with pI 3.0 were completely inactivated at $60^{\circ} \mathrm{C}$, but isoenzymes with pI 6.5 were practically inactivated at $45^{\circ} \mathrm{C}$. The internal isoenzyme with $\mathrm{pI} 4.5$ showed an intermediate behaviour.

Effect of substrate concentration on isoenzyme activity was determined over a range of substrate concentrations from 0.05 to $4 \mathrm{~mm}$ at different $\mathrm{pH}$ values; $0 . \mathrm{I}$ M-acetate buffer was used over a range from $\mathrm{pH} 3.5$ to 6.0 . The Lineweaver-Burk plots were linear, within experimental error, for the different isoenzymes, with the exception of those with pI 6.5 that were linear only for substrate concentrations from 0.5 to $4 \mathrm{~mm}$. The different $K_{m}$ values obtained are represented in Fig. 8. Isoenzymes with the same isoelectric point behaved very similarly. Isoenzymes with $\mathrm{pI} 3.0$ had $K_{m}$ values between $0.12 \mathrm{mM}$ at $\mathrm{pH} 3.5$ and $0.9 \mathrm{~mm}$ at $\mathrm{pH} 6$, those with $\mathrm{pI} 6.5$ varied from $\mathrm{I} \cdot 0 \mathrm{mM}$ at $\mathrm{pH} 4.5$ to $2.5 \mathrm{mM}$ at $\mathrm{pH} 6$, and the internal isoenzyme with $\mathrm{pI} 4.5$ showed a variation from $0.19 \mathrm{~mm}$ at $\mathrm{pH} 6.0$ to $2.5 \mathrm{~mm}$ at $\mathrm{pH} 3.5$.

Molecular weight determinations. Assuming that the molecular shape of AF isoenzymes is similar to those of the marker proteins, the approximate molecular weights were: for both isoenzymes with pI 6.5,40000; for the internal isoenzyme with $\mathrm{pI} 4 \cdot 5,350000$; and for the external one with $\mathrm{pI} 3 \cdot 0,220000$. Samples of internal isoenzymes with $\mathrm{pI} 3.0$ from several isoelectric-focusing runs always gave a very wide peak in Biogel P-300, with two apparent maxima corresponding to molecular weights of approximately 220000 and 125000 . 


\section{DISCUSSION}

In a previous paper, Fielding \& Byrde (1969) showed that $\alpha$-L-arabinofuranosidase can exist in culture filtrates of Sclerotinia fructigena in multiple forms and suggested a possible interconversion of these forms. In other fungi, such as Neurospora crassa, multiple forms of invertase that can be interconverted are related to biosynthesis and secretion of that enzyme (Metzenberg, 1964).

AF activity was found to be present both in the culture filtrate and in the mycelial homogenate of Sclerotinia fructigena when the fungus was grown in an ammonium tartratesodium polypectate liquid medium. Both activities had different physical and kinetic characteristics. The presence of at least two isoenzymes in the culture filtrate and three in the mycelial homogenate in different proportions in each preparation can account for these differences. Comparative studies suggest that the extracellular isoenzymes are identical to the internal ones with the same isoelectric point.

Isoenzymes with $\mathrm{pI} 3.0$ and 6.5 were shown to have maximum activities and to be more stable at low $\mathrm{pH}$ values: this seems to be a general characteristic of extracellular $\alpha$-L-arabinofuranosidase already studied from different plant-pathogenic fungi (Kaji \& Yoshihara, 1969). By contrast, the internal isoenzyme with $\mathrm{pI} 4.5$ was more stable and had maximum activity near or above $\mathrm{pH} 7 \cdot 0$.

While the molecular weight of the main AF isoenzyme in the culture filtrate was about 40000 , that of the other was 220000 . Secretion of isoenzymes with different physical and kinetic characteristics is not rare amongst plant-pathogenic fungi. These differences, such as size and diffusibility of enzyme molecules, may have an important role in sequential degradation of host-cell-wall polysaccharide (Goodman, Kiraly \& Zaitlin, 1967; Olutiola \& Ayres, 1973).

Trevithick \& Metzenberg (I966) in studies of secretion of invertase in Neurospora crassa suggested that the high molecular weight isoenzyme underwent molecular sieving by fungus cell walls, so explaining why the 'heavy' isoenzyme was the main component within the mycelium and the 'light' isoenzyme the main one in the culture filtrate. Molecular weight determination of the different AF isoenzymes in Sclerotinia fructigena showed that the main isoenzyme in the mycelial homogenate, which was never detected in culture filtrates, also had a high molecular weight, while the main isoenzyme in the culture filtrate had a molecular weight approximately one-tenth of that of the internal one.

F. Laborda thanks the Spanish Ministerio de Educación y Ciencia for financial support.

\section{REFERENCES}

AkInREFon, O. A. (1968). Studies on the $\alpha$-L-arabinofuranosidase of Phytophthora palmivora (Butl.) Butl. New Phytologist 67, 543-556.

Albersheim, P., Jones, T. M. \& English, P. D. (I969). Biochemistry of the cell wall in relation to infective processes. Annual Review of Phytopathology 7, I 71-194.

ANDrews, P. (1964). Estimation of the molecular weights of proteins by Sephadex gel filtration. Biochemical Journal 9r, 222-233.

Bateman, D. F. \& Millar, R. L. (I966). Pectic enzymes in tissue degradation. Annual Review of Phytopathology 4, II9-146.

Byrde, R. J. W. \& Fielding, A. H. (1965). An extracellular $\alpha$-L-arabinofuranosidase secreted by Sclerotinia fructigena. Nature, London 196, I 227-1228.

Byrde, R. J. W. \& Fielding, A. H. (1968). Pectin methyl trans-eliminase as the maceration factor of Sclerotinia fructigena and its significance in brown rot of apple. Journal of General Microbiology 52, 287--297. 
Calonge, F. D., Fielding, A. H. \& Byrde, R. J. W. (1969). Multivesicular bodies in Sclerotinia fructigena and their possible relation to extracellular enzyme secretion. Journal of General Microbiology 55, $177-184$.

FIELDING, A. H. \& BYRDE, R. J. W. (1969). The partial purification and properties of endopolygalacturonase and $\alpha$-L-arabinofuranosidase secreted by Sclerotinia fructigena. Journal of General Microbiology $\mathbf{5}^{8}$, $73-84$.

Fielding, A. H. \& Hough, L. (1965). The synthesis of $p$-nitrophenyl- $\alpha$-L-arabinofuranoside. Carbohydrate Research I, 327-329.

Fuchs, A., Jobson, J. A. \& Wonts, W. N. (1965). Arabanases in phytopathogenic fungi. Nature, London 206, 714-7I5.

Goodman, R. N., Kiraly, Z. \& Zaitlin, M. (1967). In The Biochemistry and Physiology of Infectious Plant Diseases, p. I42. Princeton: D. van Nostrand.

Howell, H. E. (1972). Production of extracellular enzymes by Sclerotinia fructigena Aderh. \& Ruhl.: some observations on their importance in pathogenesis and on their inheritance. Ph.D. Thesis, University of Bristol.

KaJI, A. \& Yoshinara, O. (1969). Production and properties of $\alpha$-L-arabinofuranosidase from Corticium rolfsii. Applied Microbiology I7, 910-913.

Keegstra, K., English, P. D. \& Albersheim, P. (1972). Four glycosidases secreted by Colletotrichum lindemuthianum. Phytochemistry Ir, $1873-1880$.

Laborda, F., Hislop, E. C., Fielding, A. H. \& Byrde, R. J. W. (I972). $\alpha$-L-Arabinofuranosidase of Sclerotinia fructigena. Journal of General Microbiology 73, xx.

Liras, P. \& GASCON, S. (I97I). Biosynthesis and secretion of yeast invertase. Effect of cycloheximide and 2-deoxy-D-glucose. European Journal of Biochemistry 23, 160-165.

Lowry, O. H., Rosebrough, N. J., Farr, A. L. \& Randall, R. J. (I95I). Protein measurement with the Folin phenol reagent. Journal of Biological Chemistry 193, 265-275.

Metzenberg, R. L. (1964). Enzymically active sub-units of Neurospora invertase. Biochimica et biophysica acta 89, 29I-302.

Olutiola, P. O. \& Ayres, P. G. (1973). A cellulase complex in culture filtrate of Rhynchosporium secalis (Barley leaf blotch). Transactions of the British Mycological Society 60, 273-282.

Teorell, T. \& Stenhagen, E. (1938). Ein universal Puffer für den pH-bereich 2,0 bis i2,o. Biochemische Zeitschrift 299, 4I6-4I9.

TREVithick, J. R. \& MEtzenberg, R. L. (1964). The invertase isoenzymes formed by Neurospora protoplasts. Biochemical and Biophysical Research Communications I6, 319-325.

Trevithick, J. R. \& MetzenberG, R. L. (I966). Molecular sieving by Neurospora cell walls during secretion of invertase isoenzymes. Journal of Bacteriology 92, roro-1015.

VESTERBERG, O. \& SVENSSON, H. (I966). Isoelectric fractionation analysis and characterization of ampholytes in natural $\mathrm{pH}$ gradients. IV. Further studies on the resolving power in connection with separation of myoglobins. Acta chemica scandinavica 20, 820-834. 